\title{
Possible Directions of Applications of IAS/IFRS in Kosovo and Comparative Aspects
}

\author{
Nexhmie Berisha-Vokshi \\ University of Prishtina, Prishtina, Kosovo
}

\begin{abstract}
Current accounting development in Kosovo is estimated to be relatively good, which always constituted in terms of maintenance, improvement and facilitate of financial reporting system for all business entities within this system. In recent years, Kosovo experienced rapid development in economic and social aspects, along with all effects and other changes, which has occurred in the development of accounting and financial reporting system. Accounting requirements are already addressed to the business community for keeping proper accounting in accordance with existing international and Kosovar standards. In recent years in Kosovo, we notice an increase of enterprises in the number, especially private enterprises, which have highlighted the great necessary to have such information, who had been a major help for their managers. With this, the accounting gets a new role, becoming the information that flows from that decisive leadership bodies. But the changing of role of accounting must be accompanied by measures to ensure its retention in accordance with the requirements and new conditions created.
\end{abstract}

Keywords: accounting standards, financial information, financial statements, financial reporting

\section{Introduction}

Actually, considering the new developments in the accounting field that are occurring in Europe, which are in terms of implementation of international accounting standards (IAS), also in Kosovo, there is building a new base of financial reporting in light of international standard, which requires business units to report to their base.

These standards are developed at national level and consistent with IAS, which came as a requirement of the users of accounting information to ensure their interests. In terms of international cooperation, Kosovo businesses should have a new approach towards the internationalization of entrepreneurship and the creation of numerous of economic and trade relations. In this case, based on the current level of economic development, there must create the first and foremost infrastructure and business environment to produce real information as to increase the reliability and attractiveness of Kosovo in internationally plan.

\section{Current Accounting Development in Kosovo-International Accounting Standards and Need of Accounting Regulation}

Currently, Kosovo is presented with new financial reporting in accordance with international accounting

Nexhmie Berisha-Vokshi, Ph.D., Professor, Economic Faculty, University of Prishtina.

Correspondence concerning this article should be addressed to Nexhmie Berisha-Vokshi, street “Idriz Gjilani” nr. 64 Prishtina 10000, Kosovo. E-mail: nexhmie_vokshi@yahoo.com. 
standards ${ }^{1}$ /international financial reporting standards (IAS/IFRS) (Georgette \& Wild, 2000), in order that financial statements to produce accounting information as transparent and quality for all users.

So, accountants that built the financial statements of Kosovo's businesses are burdened with adherence to standards. Given the fact that the level of acceptance of accounting standards depend on culture and development level of its accountants, we tried to take an assessment ${ }^{2}$ in relation to accounting development in Kosovo. To be known by their attitude and their opinions regarding this issue, we analysed the response to the question of making the questionnaire designed for this purpose: How you see the current accounting developemt in the field of accounting regulation? This question was addressed business accountants and of course their answers help us to assess their level of awareness regarding the implementation of standards, and to determine the necessity of acting in the future for increasing the full viability of them.

From all the surveyed accountants on, this questions shows that $66 \%$ were of the opinion that such current developments in the accounting field, view as good and very good and necessary, while $20 \%$ consider that such developments is not sufficient at present, so it should work even more in the future to fill this gap (see Figure 1).

How you look the at current developments in accounting regulation field?

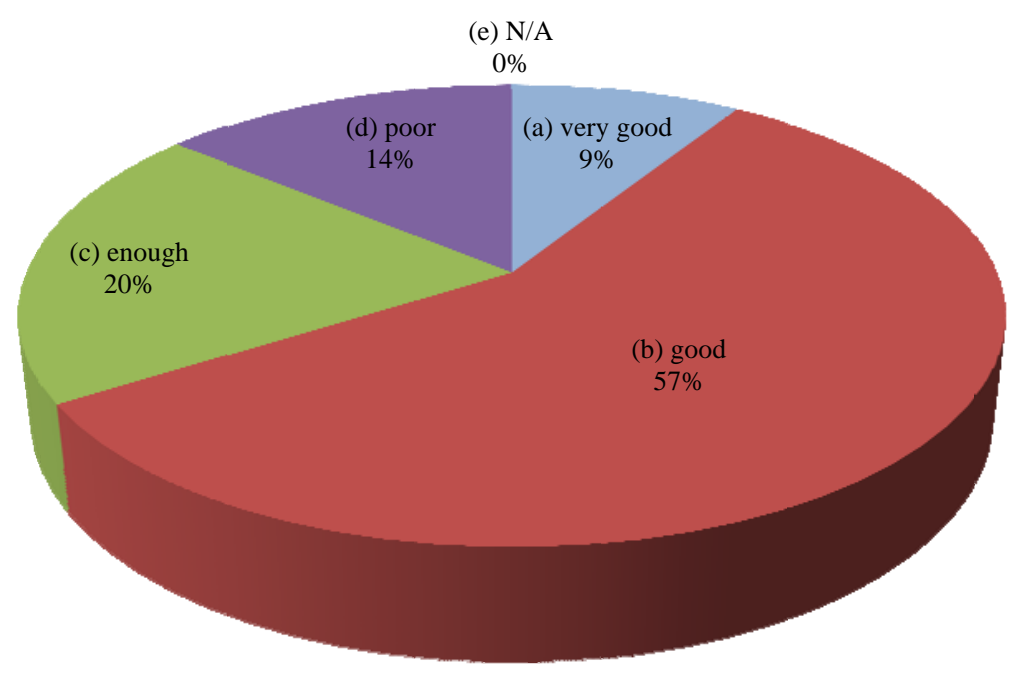

Figure 1. Current developments in accounting regulation field.

On the other hand, considering the transitional period through which are passing, of course there are gaps in the awareness of businesses to show a high level of reporting. However, the indicator presented above is positive and shows good premise for further development of accounting in Kosovo. Also we consider that the expected positive developments in legal and economic field, establishment of laws, regulations and other economic and

\footnotetext{
${ }^{1}$ IFRS issued by the International Accounting Standards of the Board IASB, an independent authority that decides for standards, based in London. IASB announced in 2001 that its accounting standards would be called IFRS-International financial reporting standards. Also in April 2001, the IASB declare that it will adopt all IAS issued by the IASC and the term IFRS also includes IAS, and all relevant interpretations. With other words, the IFRS are standards and interpretations used by the international accounting standards (IASB).

${ }^{2}$ Four hundred people were surveyed: Selected campon: 212 accountants employed in trade enterprise (75.5\%), service (8\%), manufacturing (1.9\%), post (1.6\%), banks (9.9\%), insurance companies (0.9\%), KPS (1.9\%). Except them are also interviewed 59 independent accounting and auditing, 35 employees in tax administration, 8 employees in the Chamber of Commerce, and 86 directors in small, medium and large enterprise (73\%), in the bank (12.7\%), insurance companies (9.3\%), post (4.6\%).
} 
legal measures, will do to reach and cultivate a culture of accountability and quality of his reporting on the all societies.

The preparation of financial statements with IAS is an essential requirement, and the interior of Kosovo's development. First, this is justified with the issue of globalization (Maree \& Chalmers, 2006) of the economy and integration into the European Union.

Using these standards means the financial reporting with a unique language of accounting used in most development countries (Glautier \& Underdown, 2001). And from this stems, first, transparency in reporting, then the comparability of the financial statements with those of other countries, creating a balance in excess of group interests, creating a compromise inter-business, and manufacturing business reports with the legitimacy and full credibility.

When we consider the general purpose of financial statements, which is to provide information accessible and understandable to all its users, then this is probably already recognizes the unique basis of financial reporting in conformity with IAS. Their implementation assists in the generalization of the format of financial reporting and comparability of financial results on a global degree.

And also it helps to simplify the statements, because applying unique accounting rules comes to elimination of some elements of mischief, which would exist if they will apply different reules in reporting (Dhamo, 2005).

Given the very great importance of the implementation of international standards, this study will help to identify and eliminate barriers to the realization of this process, clearly defining core element of the importance and to clear the path that leads toward their full implementation.

\section{Comparative Experiences Relating to the Development of Accounting Under IAS/IFRS}

The experience in developing of accounting and auditing profession in the region, serves as the basis for recognizing the best level of development of this profession in Kosovo, serving the best practices of these countries related with system education for international accounting standards.

By analysing the level of development of accounting in some places around, we can support the decisions of professional authorities for future developments.

The passing of time and comparing of such experiences, measured progress of profession and facilitate the communication and trade with accounting services. Obviously, the development of country's accounting depends on several features, such as cultural history, legal system, then the economic position and level of higher education.

Therefore, the following will do an analysis of accounting development in the region, in oreder to have access development level of accounting and implementation of IAS.

Such experience will enable us to use comparability of development of professional accounting among countries, getting good practice and presenting needed recommendations.

\section{Accounting Development in Serbia}

Thus in Serbia, according to data of ROSC report (2005), we have a thorough assessment of the practices and accounting policies. In this case, report also takes into account Asquis communnatuaire ${ }^{3}$, which has double significance for Serbia, because it introduces a model of high quality for accounting, as well as for the

\footnotetext{
${ }^{3}$ Asquis communnatuaire- thus called all EU laws together. This term is used more by countries that intending to join the EU. They should to approve, implement and enforce all parts of Asquis in order to be accepted to join the EU.
} 
development of Serbia for integration in European Union.

Serbian Law on Accounting and Auditing (AA, Law, 2002) since 2004 has required the implementation of IAS for all enterprises, and since 2003 there required the application of these standards to the financial statements of financial institutions. According to this law, financial reports should include: balance of sheet, the statement of income, statement of cash flows, statement of changes in own capital and financial reporting and explanatory notes. Courses for provided reporting for small and medium enterprises, only balance sheet and income statement are provided as required.

Annual financial reports submitted to the Central Bank of Serbia. Submission of reports by the entities become legal order, which first presented the annual financial statements, then the consolidated financial statements at the end of the consolidated financial statements together with the opinion of the auditor.

As additional obligation, all companies are required audit of statements, then their publication together with the auditor's opinion on their websites, so that the public has access to them. The audit of financial statements for medium and large enterprises is mandatory. These documents should be allocated according to the elements presented in the accounting framework, which is presented by the Ministry of Finance, and as such is designed to represent all transactions in accordance with IAS and IFRS ${ }^{4}$.

But such a request must be monitored, as well as in Serbia, the implementation of international standards is still a challenge, which is not easily to cope with, especially for small enterprises to make sure that costs do not exceed the benefits.

Thus, the Law on Accounting and Auditing (2002) requires from the government to establish a Committee on Accounting and Auditing (CAA), which will oversee the development of accounting.

It will be responsible for:

- Monitoring and professional development and implementation of IAS and IFRS;

- Adoption of national standards of accounting and auditing;

- Supervision of the quality work by professional regulatory authorities.

A favourable situation currently contributes to the level of professional preparation in college, such work always in function for the professional support. Thus, Economic Faculty at the University of Belgrade, has developed courses at several levels including the code of ethics for professional accounting (IFAC), IAS and IFRS.

If we analyse the current level of development in Serbia, based on the above data, there is a relatively good level of development of accounting in conformity with international standards, increasingly with trend of continuous development of the profession through professional training of responsible persons and development of monitoring system in line with VIII European Directive, providing quality in implementation of interests of the public. Also, the application of this country by the government to create a commission for monitoring the

\footnotetext{
${ }^{4}$ Board for financial reporting in Kosovo was established on October 29, 2001 with UNMIK regulation 2001/30. This regulation, not only has defined the responsibilities of the Board, but also has placed the financial requirements and financial reporting for business organizations in Kosovo. The work and activity of the Board has been essential to the economy of Kosovo, because it has set the objective standard, transparent and internationally recognized accounting and auditing, on which can develop a market economy. The Board has also set standards of training and certification for accountants and auditors, who are trying to reach international standards and thus a basic human resources to assist development of the economy for interaction with the rest of Europe. The Board also ensures that standards to be of a high level in accordance with best international practice.
} 
implementation of standards, we think to serve as a recommendation for the development of such a system in Kosovo.

Also, professional support that provided by the faculty would be useful to us, and publication of financial reports to the Central Bank would be the model, which will help us to fill gaps that currently exist regarding the full access to public in financial reports of all business entities.

However, we think that should be keep in mind and the conditions of Kosovo. It is important to observe the fact that there must be a organism that monitors development of accounting, and the professions of accounting standards, that financial statements must be published to be available to the public. Also to be taken into consideration and relevant developments in European Union.

\section{Accounting Developments in Macedonia}

Similar as in other transition countries, also Macedonia is trying to establish favourable conditions for business, ready to attract potential investors and those existing.

This is also a requirement more for need of financial statements with structure well organized and transparent frame, with international language of accounting (Nolke, 2005).

It is considered as a way to increase transparency, reduce the cost of capital etc..

Adoption of IAS will be the best tools for building a financial report transparent and comparable, which will help the investors to make financial decisions better designed.

Law for the regulation of accounting and auditing in Macedonia, is the law No. 25/2004 ${ }^{5}$, which replaces the old law 1996. The new law provides for regulation of all types of companies: large, medium, small and micro. IAS are obligatory for the following companies, classified by size and financial regulation framework: large commercial companies, medium commercial companies, commercial banking companies, commercial insurance companies, listed companies on the securities market.

The law in question predict that IAS to be as single standard for preparing financial statements for these companies. All other companies that are not listed above, may prepare and submit their financial statements in accordance with IAS, if they choose well.

The law requires audit of large and medium enterprises in accordance with international standards on auditing (ISA). The auditor is obliged to support the code of professional ethics for audit.

Macedonia is at the early development of a modern financial reporting framework.

IFRS are required for all companies, however, actually many companies are already in the initial phase of their transition. IFRS recently has been retranslated and included in the law. Markets participants (but also the experience of countries in the region) suggest that, achieving the high quality of IFRS, for many companies is in early stage, so it should take into consideration extra time and necessary support.

Macedonia is trying gradually to improve the quality, comparability and transparency of accounting information of companies, to improve the quality of the audit, to comply in accordance with IAS and IFRS, and with asquis communnitaire. Accounting and auditing were regulated by the law of Companies (1996), audit law (1997), and recent legislation adopted the basics of these laws. The government soon also prepared a new law (2004), which included the adoption of IAS and IFRS issued by the international accounting standards of Board

\footnotetext{
${ }^{5}$ Trade company law, Official Gazette, No. 28/2004.
} 
(IASB), and translated and presented in the official gazette.

However, Macedonia is estimated at the early stage of adoption of standards, and the development of the accountancy profession is on not right level, although some faculties curricula began to include IAS in their programs, still not adhered to the programs and the full placement programs and curricula.

There was actually a law regarding the establishment of penalties in case of violation of the law.

Such a presentation we find to the law on accounting ${ }^{6}$, where in article 80 provided penalties measures 60,000 to 300,000 DEN should be punished for violating the law (all points of violation are described in section 80, 81, and 82 of this law $^{7}$ ). Generally observed a difference between the level of regulation accounting and IAS, and consistent with them to the level of practical implementation of these regulations by the accountants, the enterpreneurs, the users of accounting information, and a number of other socio-economic-political factors.

\section{Accounting Developments in Albania}

Albania for a period of over 10 years implemented an accounting regulation oriented by continental school of accounting, and accordingly the French model.

So the regulation was based on a law to regulate in detail the maintenance of accounting and main financial statements. Also had a unique account plan, which was a legal obligation to be implemented by all units.

But after the changes occurring at international level, and respectively at European level, in the accounting field, and in Albania there begin efforts to new accounting regulations based on international standards.

Implemenetation of IAS begin with drafting a new strategy for reform in the accounting field.

Such work was aimed at improvements in accounting regulation with increased transparency, reliability of financial information, to meet the needs of users and to protect the interests of the public.

Therefore in 2006, and as for standards, on January 1, 2008, were identified principles and general rules for preparing the national standards and financial statements.

Two packages were selected to applicable standards in Albania (as well in Kosovo): a category of entities, mainly those in the public interest (banks, financial institutions, insurance companies), necessary have to apply IAS/IFRS, processed and published by the IASB, and translated into Albanian; whereas other units implement national standards that are consistent with IAS. Also it created an application of accounting adjustments, which is the National Accounting Council. But current law which begun implementing the new standards from 1 January 2008, does not anticipate the establishment of penalities in cases of non-enforcement of the law, with an idea that the damage causes by failure of the law would be subject of conflicts and civil cases in court. But Albania's legal culture has difficulties to provide a receipt of this order regulation. Also about the professions, in Albania since 2008, there is accounting and auditing profession and relevant professional organism (IEKA), which is regulated by a decision of the council of ministers. In Albania, there was a legal arrangement of approved accountants, which is not valide with the introduction of the new law on accounting and financial statements in 2004.

This means that there is a legal gap in terms of regulations of these professions currently.

Thus, in Albania, this law has affected quite well in creating new conditions in accounting regulation, defining the obligations (listed) for the application of standards, for processing accounting system, establishes

\footnotetext{
6 The law on accounting, published in "The Official Gazette of the Republic of Macedonia”, nr.42/93 doc.48/93.6/95.

7 The law was published also in "The Official Gazette of the Republic of Macedonia”, nr.42/93 doc. 48/93. 6/95, Constitucional Court nr.C.C No. 247/95, 248/95, 304/95 in 3/06, 32/98, 39/99 and 70/2001.
} 
basic rules for keeping accounting, principles for the construction of financial statements etc.. Obviously, the implementation of standards and all rules above in Albania are created conditions for significant progress in view of the stability of financial reporting, with new changes and relevant news that brought a new breath of reporting. As special of this, it is worth mentioning that freedom for keeping accounting by accountants is growing, and also their responsibility.

All this progress is achieved by mutual cooperation of all parties involved in this case, auditors, accountants, consultants, market participants, interested students etc..

So, the existing law (2004) in Albania, with the objective to improve financial reporting, set the stage for coordination with asquis communautaire, and international standards and practices. However, Albania, as well as Kosovo, have taken further steps to achieve the main goals, forming a powerful reporting framework, accounting to local needs to be in line with European laws, because the existing framework is not always consistent and complete, limited technical and financial resourses contribute to the vulnerability of institutions.

It is more than necessary to strengthen institutional and professional capacity, perhaps it is a lack of human capital in such areas, as the drafting of accounting standards and audit, their updating, monitoring and enforcement, the preparation and auditing of financial statements (Chambers, 2006). Then in small and medium enterprises, transparency of financial information is estimated to be low, because of the abstence of financial statements and informality, etc., it contributes to distrust of the third parties, who are not well informed about condition of these units (especially when we consider SMEs constitute the highest percentage of entities, this problem is serious). Also Law of Accounting and Financial Statements does not provide accounting arrangement simplified for micro-enterprises.

\section{Common Recommendations}

(1) There is a need for continuation of the arrangements in the field of standardization of accounting being accompanied with the issuance of guidelines and regulations in form of various instructions of accounting thus facilitating the implementaion of new accounting rules;

(2) Sustainability of the necessary changes can not be done without the support and assistance qualified of external expertise and without absorbing and drawing experience and expertise of best local specialists;

(3) Help and financial support-inclusion of these countries in international standard establishes the cost, which is not easily borne by the economy of these countries. This requires, not only investment by entities and accountants, but also financial support from the state and international organizations, for training, structural and organizational assistence, legal etc.;

(4) Continued development of the profession of accountants: legal auditors and other accountants. Required adjustment of the relevant laws in order to ensure a development of the professions monitored by public authorities but also by the necessary level of self-regulation by profesional authorities;

(5) Professional qualification should be recognized internationally, at least, it is in desperate need in the region. This means to ensure adequate institutional capacity to facilitate interregional training in the field of IAS/SNFR and unified audit at the regional level enabling the free exchange of professionals within the region;

(6) Must be determined and appropriate accounting adjustments for microenterprises by facilitating and lowering the cost of accounting and their financial reporting; 
(7) Require a better alignment between accounting reporting and that for tax purposes;

(8) University programs and professional trainers have to be updated, contain the necessary courses and harmonization between theory and practice;

(9) Generally in the region which are urgent and critical areas identified in connection with the implementation of IAS, so should work with partners, donors to cover these gaps.

Such a work will contribute to:

(1) Regional integration;

(2) Development of the economy of its globalization...

And it will result with:

(1) Increased confidence in public and private sector;

(2) Increased confidence in the accounting profession;

(3) Reliability, comparability, readability of financial reports...

\section{References}

Anonymous. (2007). Draft law for financial reporting enterprises.

Chambers, R. J. (2006, June). Abacus: A true and fair view of the principles. Journal of Accounting, Finance and Business Studies, Scolarly Articles, 42(2), 132-164.

Dhamo, S. (2005, March). Advanced accounting (pp. 353-428). Tirana.

Georgette, T. B., \& Wild, K. (2000). International accounting standards. In Deloitte Touche Tohmatsu International (p. 36) (3rd ed.).

Glautier, M. W. E., \& Underdown, B. (2001). Accounting theory and practice (7th ed.). London.

Godfrey, J. M., \& Chalmers, K. (2006, October). An analysis of globalization of accounting standards. Journal of Modern Accountinting and Auditing, 2(10).

Kemp, P. S., \& Philip, M. E. (1989). Advanced accounting.

Nolke. (2005). The globalization of accounting standards. Journal of Business and Politics, 7(1).

Stickney, C. P., \& Weil, R. L. (2006, August 16). Financial accounting: An introduction to concepts, methoods and uses (12th ed.). USA.

UNMIK. (2001). Regulation No. 2001/30 On the Establishment of the Board for Financial Reporting of Kosovo and Financial Reporting Regime of Afarist, Unmik-official Gazette. 